Bangladesh J. Bot. 48(4): 1001-1010, 2019 (December)

\title{
EFFECTS OF INTERACTION OF BIOCHAR AND NITROGEN FERTILIZER ON GROWTH, YIELD AND YIELD COMPONENTS OF SOYBEAN
}

\author{
LiU Ming, Bi Ying-Dong, Li Wei, LiU Miao, Wang Ling, \\ Di Shu-Feng and Lai Yong-CaI* \\ Cultivation and Crop Tillage Institute of Heilongjiang Academy of Agricultural Sciences; \\ Harbin; Heilongjiang, 150086, China
}

Keywords: Soybean, Biochar, Nitrogen, Interaction effect

\begin{abstract}
Effects of the interaction of biochar and nitrogen fertilizer on the growth, yield and yield components of soybean were studied in cylindrical tube cultivation. The results showed that proper application of biochar promoted dry matter accumulation and LAI regulation of individual plant, and the regulating effect was greater in the later stage of growth than in the early stage. The dry matter weight per plant and LAI were the highest in $\mathrm{C} 1$ treatment with different amount of biochar application. However, with the further increase of the amount of carbon application, the dry matter weight per plant and LAI decreased gradually. The plant height of soybean was reduced by the application of biochar. $750 \mathrm{~kg} / \mathrm{hm}^{2}$ of biochar and $42 \mathrm{~kg} / \mathrm{hm}^{2}$ of nitrogen were found to be the best combinations for high yield of soybean and the theoretical yield was found to be $3546.9 \mathrm{~kg} / \mathrm{hm}^{2}$. The combination of biochar and nitrogen fertilizer affects yield mainly by regulating the number of seed per plant.
\end{abstract}

\section{Introduction}

Biochar is the product of biocharation of crop straw and other organic materials after pyrolysis at high temperature under the condition of no oxygen or low oxygen. Previous studies have used biochar as a soil amendment (Novak and Busscher 2012). It has many functions such as improving soil quality and maintaining soil fertility. The disadvantage is that the nutrient content is low (Lehmann 2007, Woods and Falcao 2006, Zhou et al. 2011). Biochar has special micropore structure and strong adsorption ability and can adsorb and immobilize the mineral elements necessary for plant growth in soil, and effectively regulate the cycling of nutrient elements in soil (Lehmann et al. 2011, Altland and Locke 2013, Randolph et al. 2017). It can effectively improve soil physical and chemical properties, reduce nutrient leaching and volatilization, and ensure adequate nutrient supply (Headlee et al. 2014, Liao et al. 2016, Lucheta et al. 2016) and also change the structure of soil microbial community, affect the growth and activity of microorganisms, and then affect the growth of crops (Bruun et al. 2014, Rehrah et al. 2016, Xu et al. 2016). Biochar has a strong adsorption effect on ammonium nitrate nitrogen in soil, which can slow down nitrogen leaching loss, improve soil nitrogen retention capacity and promote nitrogen uptake and utilization efficiency of crops (Zheng et al. 2013). Biochar causes effective reduction of leaching and loss of nitrogen from the ground surface and improvement of soil fertility (Olmo et al. 2014). Biochar can also directly adsorb ammonium nitrogen, nitrate nitrogen and ammonia from soil, or accelerate ammonia volatilization to change the availability of nitrogen (Chen et al. 2013, Clough et al. 2013).

Agegnehu et al. (2016) reported that plant growth will be inhibited, and crop yields will be reduced by applying only biochar without applying exogenous nitrogen fertilizer. The effect of

\footnotetext{
*Author for correspondence: <liuming666@126.com>.
} 
mixed application of biochar and chemical fertilizer on crop yield is obvious (Partey et al. 2014, Li et al. 2015, Gul and Whalen 2016, Mehmood et al. 2017). Combined application of biochar and chemical fertilizer can significantly promote the content of ammonium and nitrate in rhizosphere of soybean at flowering stage (Liu et al. 2014). Synergism of biochar and fertilizer resulted in significant increase of soybean biomass and seed yield (Schnell et al. 2012, Mete et al. 2015). The average yield of soybean increased by $10.1 \%$ after applying biochar (Zhang et al. 2015). The total amount of protein and fat after mixed application of biochar and chemical fertilizer is obviously better than that of single fertilizer application.

However, there are scanty reports on the interaction between biochar and nitrogen and their dose-effect relationship, and there are a few reports on the effects of biochar on soybean growth, development and yield formation. Therefore, through the application of biochar in soybean, the regulation mechanism of biochar on soybean growth, development and yield formation was studied, and the dose-effect relationship between biochar and fertilizer was clarified. The feasibility of its application in soybean production provides theoretical basis for improving soybean yield and fertilizer utilization efficiency.

\section{Materials and Methods}

HF 55 of soybean variety was selected as experimental materials. Biochar particles were produced by maize straw and granular size is $1.5-2 \mathrm{~mm}$.

The pot incubation test took place at Heilongjiang agricultural demonstration zone in Haerbin,

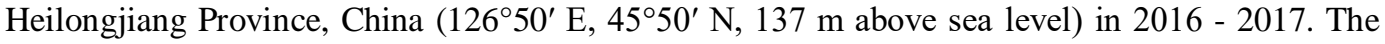
climate is temperate continental monsoon. Annual average temperature was $3.6^{\circ} \mathrm{C}$, frost-free season $135 \mathrm{~d}, 10^{\circ} \mathrm{C}$ or higher accumulated temperature was $2757.8^{\circ} \mathrm{C}$. Annual average rainfall was $524 \mathrm{~mm}$. Relevant soil properties were as follows: rapid nitrogen $(\mathrm{N}) 122.2 \mathrm{mg} / \mathrm{kg}$; rapid phosphorus $\left(\mathrm{P} ; \mathrm{P}_{2} \mathrm{O}_{5}\right) 56.5 \mathrm{mg} / \mathrm{kg}$; rapid potassium $\left(\mathrm{K} ; \mathrm{K}_{2} \mathrm{O}\right) 247.5 \mathrm{mg} / \mathrm{kg}$; total nitrogen $0.16 \%$; organic matter $35.8 \mathrm{~g} / \mathrm{kg}$ and $\mathrm{pH} 7.17$.

Tube culture was adopted on land for growing field crops in order to control soil fertility and to be closed to the field condition. Tube material was bottomless PVC cylindrical tube. The cylindrical tube was $15 \mathrm{~cm}$ in diameter and $42 \mathrm{~cm}$ in height. PVC cylindrical tube was dug into the soil in the spring. Setting depth was $40 \mathrm{~cm}$ and protruding through the soil level up to $2 \mathrm{~cm}$. Adjacent cylindrical tube spacing was $2 \mathrm{~cm}$ and 30 tubes were used per treatment.

The airdrying soil (filling thickness $30 \mathrm{~cm}$ ), mixture of soil, biochar (filling thickness $5 \mathrm{~cm}$ ) and mixture of soil and fertilizer (filling thickness $5 \mathrm{~cm}$ ) were filled-in cylindrical tube successively. The layers of soil bulk density were $1.2 \mathrm{~g} / \mathrm{cm}^{3}$ maintained and filled compactly. Then watering was done to keep the soil saturated on May. Five seeds were sown three day of soil culture. Three plants per cylinder tube were maintained after sprouting. Watering was done in drought. Harvest was made on October 1.

The experiment was designed for two factors and four levels. The main factor was the amount of biochar applied. The amount of biochar applied was set at 4 levels: 0, 750, 1500 and 2250 $\mathrm{kg} / \mathrm{hm}^{2}$. The secondary factors were the amount of nitrogen applied, in which pure nitrogen was set at 4 levels: $0,30,60$ and $90 \mathrm{~kg} / \mathrm{hm}^{2}$. The rate of application of biochar and nitrogen fertilizer is presented in Table 1.

The above ground parts of the plants were taken at early flowering stage (R1), full-blossom stage (R2), full-pod stage (R2) and seed filling stage (R6). The plant organs were separated according to stem, leaf, petiole and pods. The samples were packed in a sample bag and kept at $105^{\circ} \mathrm{C}$ for $30 \mathrm{~min}$, then dried at $75^{\circ} \mathrm{C}$ till to constant weight was contained, then cooled to room temperature and weighed with 1/1000 scales. The leaf area was measured by specific leaf weight 
method. Chlorophyll content (leaf color value) was determined by chlorophyll analyzer. The plant height was determined by meter scale.

Table 1. Biochar and nitrogen application rate in different treatments.

\begin{tabular}{lcc}
\hline Treatment & $\begin{array}{c}\text { Biochar application rate } \\
\left(\mathrm{kg} / \mathrm{hm}^{2}\right)\end{array}$ & $\begin{array}{c}\text { Nitrogen application rate } \\
\left(\mathrm{kg}^{2} \mathrm{hm}^{2}\right)\end{array}$ \\
\hline C0N0 & 0 & 0 \\
C0N1 & 0 & 30 \\
C0N2 & 0 & 60 \\
C0N3 & 0 & 90 \\
C1N0 & 750 & 0 \\
C1N1 & 750 & 30 \\
C1N2 & 750 & 60 \\
C1N3 & 750 & 90 \\
C2N0 & 1500 & 0 \\
C2N1 & 1500 & 30 \\
C2N2 & 1500 & 60 \\
C2N3 & 1500 & 90 \\
C3N0 & 2250 & 0 \\
C3N1 & 2250 & 30 \\
C3N2 & 2250 & 60 \\
C3N3 & 2250 & 90 \\
\hline
\end{tabular}

Average plant height, number of seeds/plant,100-seed weight (g), seed weight (kg/plant) and yield $\left(\mathrm{kg} / \mathrm{hm}^{2}\right)$ were recorded at maturity stage.

\section{Results and Discussion}

Fig. 1 shows that there were differences in dry matter weight per plant between different biochar application treatments in different growth stages and that the dry weight per plant of biochar application treatment was lower than that of non-biochar application treatment in the early stage of growth. The average dry weight per plant of $\mathrm{C} 1, \mathrm{C} 2, \mathrm{C} 3$ treatment were 38.2, 35.4, 53.9\% lower than that in C0 treatment in R1 stage and 10.8, 11.1, 39.1\% lower than that in C0 treatment in R2 stage. With the development of growth period, dry matter weight of single plant was higher than that of non-biochar treatment. The average dry weight per plant of $\mathrm{C} 1$ treatment in R4 stage was $2.9 \%$ higher than that of $\mathrm{C} 0$, but that of $\mathrm{C} 2$ and $\mathrm{C} 3$ treatments were 2.4 and $41.2 \%$ lower than that of $\mathrm{C} 0$ treatment. The average dry weight per plant in $\mathrm{C} 1$ and $\mathrm{C} 2$ treatments was 5.3 and $1.6 \%$ higher than that in $\mathrm{C} 0$ in $\mathrm{R} 6$ stage, but $30.2 \%$ lower in $\mathrm{C} 3$ treatment than in $\mathrm{C} 0$ treatment. There were differences in dry weight per plant between different nitrogen application treatments at different growth stages, which showed that the average dry matter weight per plant increased first and then decreased with the increase of nitrogen application rate, and the average dry matter weight per plant was the highest in $\mathrm{N} 3$ treatment. 

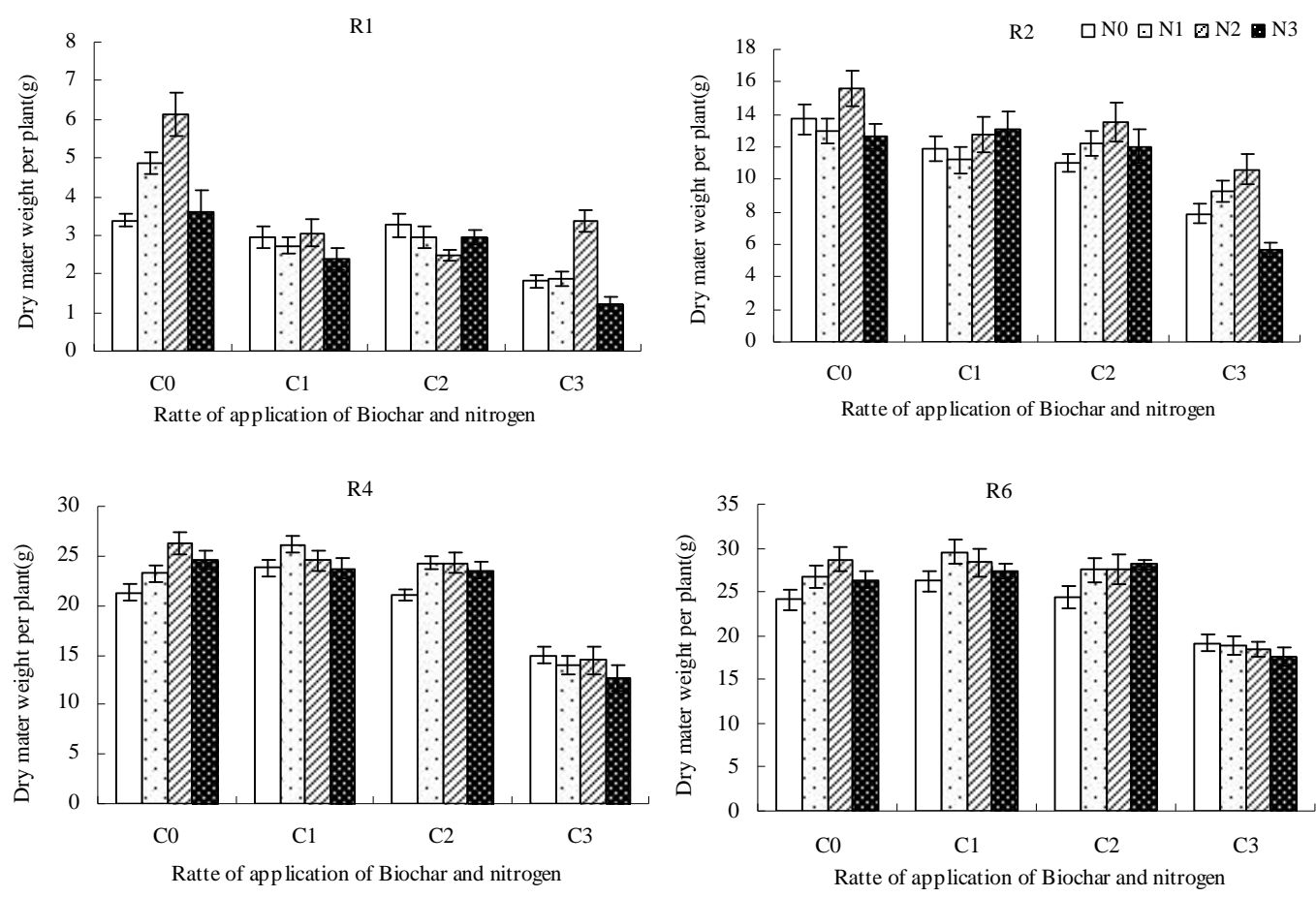

Fig. 1. Effect of rate of biochar and nitrogen application on dry matter accumulation in different growth stage of soybean.

Fig. 2 shows that the mean LAI values of $\mathrm{C} 1, \mathrm{C} 2$ and $\mathrm{C} 3$ treatments in R1, R2 and R4 stages were lower than those in $\mathrm{C} 0$ without biochar treatment. With the development of the growth period, the LAI of the treatments increased gradually. The mean value of LAI in $\mathrm{C} 1$ and $\mathrm{C} 2$ treatments was 7.34 and $4.87 \%$ higher than that of $\mathrm{C} 0$ treatment, but the mean value of LAI in C3 treatment was still lower than that of C0 treatment. The LAI of R6 stage was the largest in each growth period. There were differences in leaf area index between different nitrogen application treatments at different growth stages, which showed that the mean leaf area index increased first and then decreased with the increase of nitrogen application rate. The average leaf area index was the highest in N3 treatment.

It can be seen from Fig. 3 that the chlorophyll relative content (SPAD) increased first and then decreased in the whole growth period, and in R4 stage was the highest in each growth period. SPAD was decreased in $\mathrm{N} 3$ treatment under the condition of C0. SPAD increased with the increase of nitrogen application rate under the condition of $\mathrm{C} 1, \mathrm{C} 2$ and $\mathrm{C} 3$. There was no decreasing trend when nitrogen applied in N3. SPAD of C2 was found to be the highest.

Table 2 reveals that the average plant height of biochar treatment was lower than that of non-biochar treatment, and the average height of $\mathrm{C} 1, \mathrm{C} 2$ and $\mathrm{C} 3$ were $7.10,7.35$ and $9.79 \%$ lower than that of $\mathrm{C} 0$, respectively. The mean plant height of $\mathrm{N} 1$ was $1.62 \%$ higher than that of N0. With the increase of nitrogen application, the average plant height decreased, and the average plant height of N2 and N3 was 0.91 and $6.60 \%$ lower than that of N0, respectively. Seed number, 100 -seed weight and seed weight per plant did not decrease. Under the same biochar application level, there were differences in yield among different nitrogen application rates, and the yield 
increased first and then decreased with the increase of nitrogen application rate. Under the condition of non-biochar application, the yield of $\mathrm{N} 1$ was the highest, under the conditions of $\mathrm{C} 1$ and $\mathrm{C} 2$, the yield of $\mathrm{N} 2$ was the highest. Under $\mathrm{C} 3$ condition, the yield was the highest at $\mathrm{N} 1$.
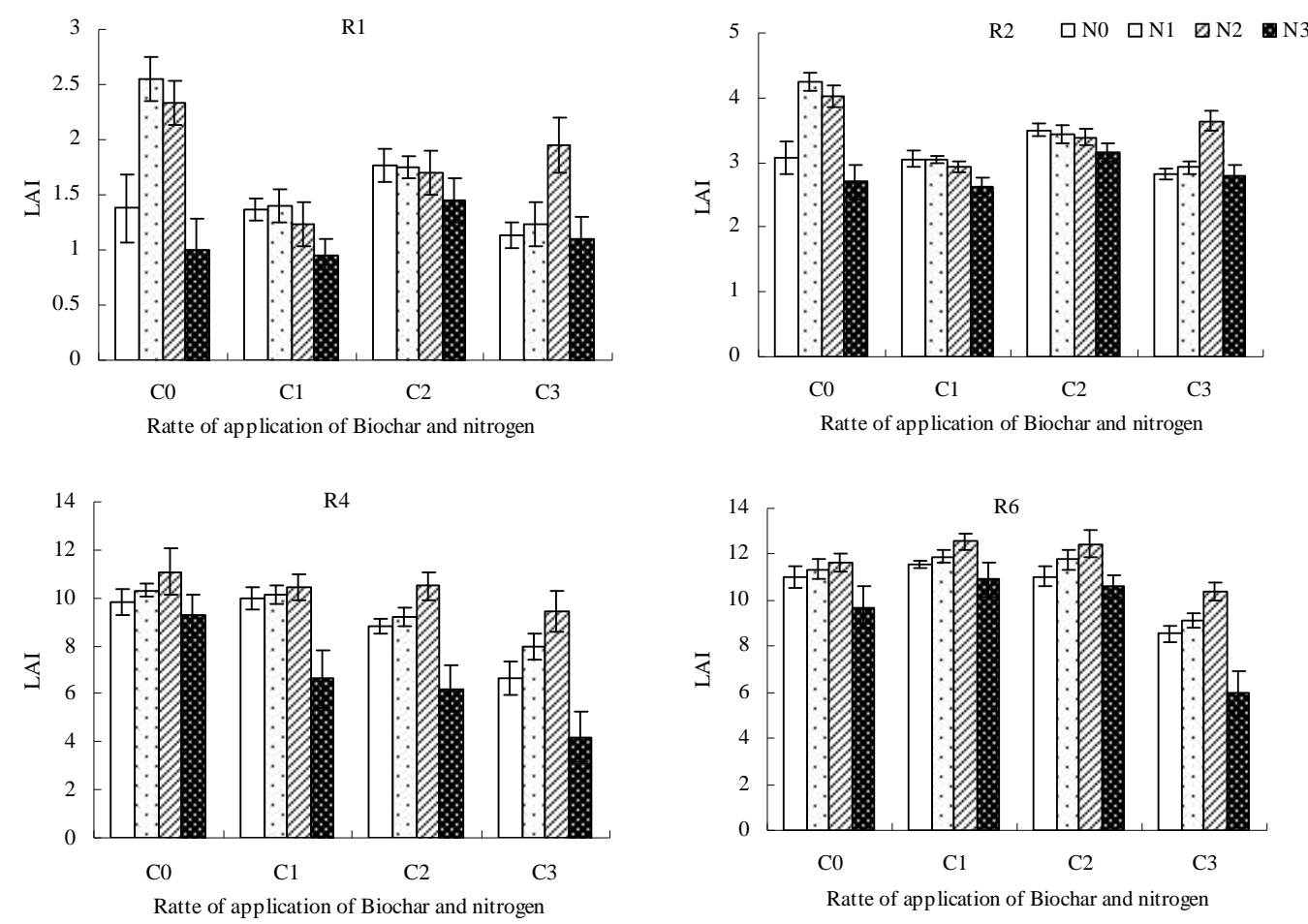

Fig. 2. Effect of rate of biochar and nitrogen application on LAI (leaf area index) in different growth stage of soybean.

The variance analysis of yield and yield components among different treatments showed that the yield and yield components of biochar fertilizer, nitrogen application amount and interaction between biochar application and nitrogen application had reached highly significant level. The results showed that the mixed application of biochar and nitrogen fertilizer had a certain regulating effect on yield. According to the correlation analysis of yield components and yield, the correlation between seed number per plant and seed weight per plant reached an extremely significant level $(r=0.99 . n=16)$. The correlation between 100 -seed weight and seed weight per plant was not significant $(r=0.16 . n=16)$. The results showed that the combination of biochar and nitrogen fertilizer mainly affected soybean yield by regulating the number of seeds per plant.

As shown in Fig. 4 that the relationship between the amount of nitrogen application and the yield of soybean can be fitted well with quadratic equation with one unknown $\left(R^{2}>0.8\right)$ at the level of biochar application, and the model presents a parabola with an opening down. X represents nitrogen rate and Y represents yield in type (Table 3). The yield of soybean increased with the increase of nitrogen application, and then continued to be put into nitrogen fertilizer, and the yield decreased after reaching the peak value. Therefore, the best benefit should be obtained before the peak value of the curve, and the amount of nitrogen applied above the peak value is an 
invalid input. According to the nitrogen regression equation, the optimum nitrogen application rate and theoretical yield can be predicted under different biochar application levels.
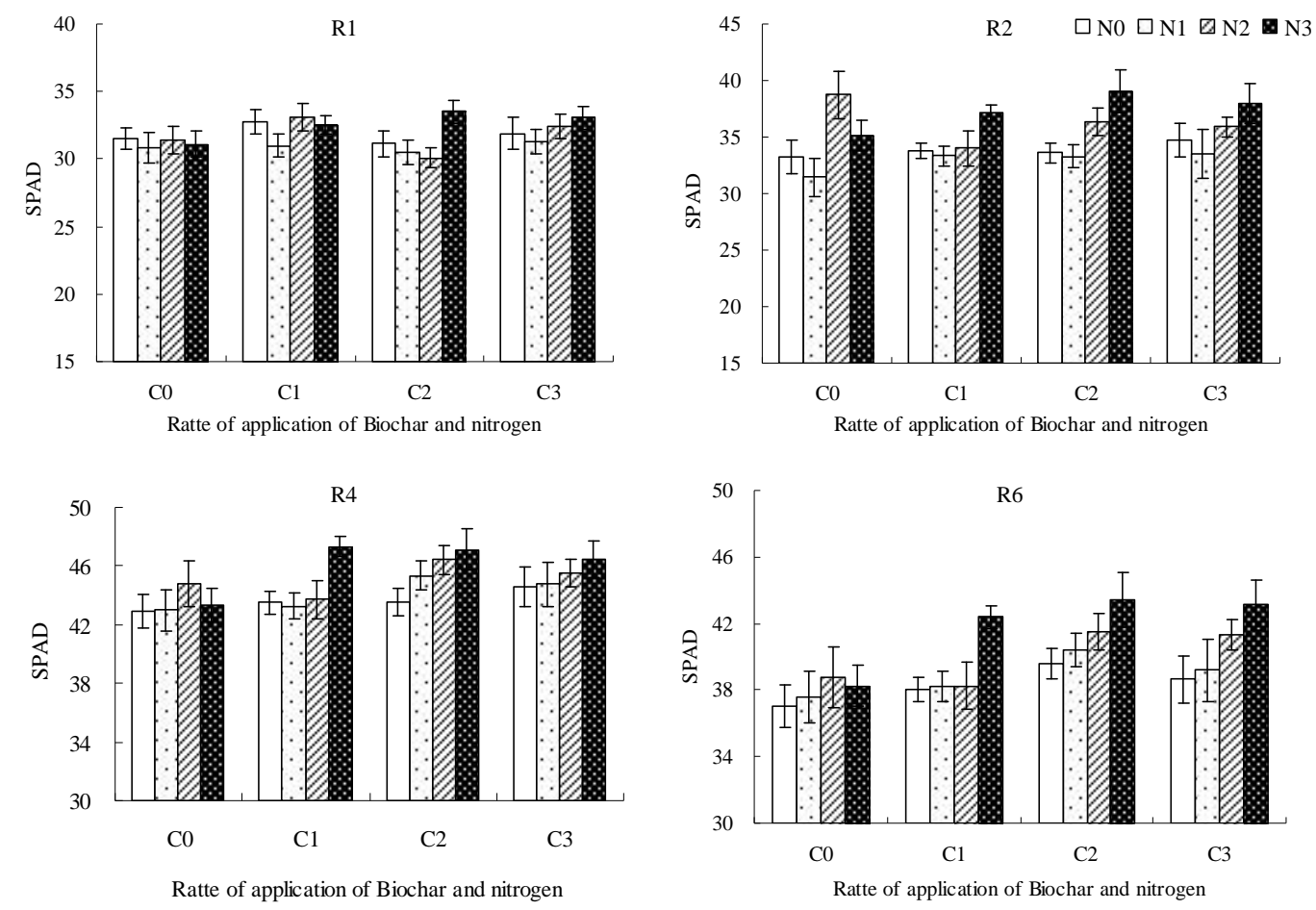

Fig. 3. Effect of rate of biochar and nitrogen application on SPAD in different growth stage of soybean.

Based on the regression equation of soybean yield and amount of nitrogen application and the relationship between amount of nitrogen application amount and yield, it was found that the optimum nitrogen application rate was the lowest under the condition of non-biochar application, and the theoretical yield is also the lowest, and the yield potential was not fully developed (Table 3). The optimum nitrogen application rate was $42 \mathrm{~kg} / \mathrm{hm}^{2}$ and the theoretical yield was 3546.9 $\mathrm{kg} / \mathrm{hm}^{2}$ when the biochar application level was $750 \mathrm{~kg} / \mathrm{hm}^{2}$, which was the highest among all the biochar application levels. When the amount of biochar continued to increase, the optimum nitrogen rate also increased, but the theoretical yield decreased. Therefore, biochar $750 \mathrm{~kg} / \mathrm{hm}^{2}$ and nitrogen $42 \mathrm{~kg} / \mathrm{hm}^{2}$ were the best combinations for soybean yield (Table 3 ).

The application of biochar inhibited the accumulation of dry matter weight per plant in the early stage of soybean growth, and the weight of the dried matter of the single plant treated by the biochar application treatment was lower than that of the non-biochar application treatment. With the development of the growth period, the inhibitory effect decreased gradually. The dry matter weight of single plant was higher in the later stage of growth than that in the treatment of non-biochar application. However, the accumulation of dry weight per plant was still unfavorable when the amount of biochar application exceeded a certain range. The single dry matter weight of the high-biochar treatment was less than that of the non-biochar applied treatment. 
Table 2. Effect of rate of biochar and nitrogen application on plant height, yield and yield components of soybean.

\begin{tabular}{|c|c|c|c|c|c|c|}
\hline \multicolumn{2}{|c|}{ Treatment } & $\begin{array}{l}\text { Plant height } \\
\quad(\mathrm{cm})\end{array}$ & $\begin{array}{l}\text { Seed number } \\
\quad \text { (Plant) }\end{array}$ & $\begin{array}{c}100 \text {-seed } \\
\text { weight }(\mathrm{g})\end{array}$ & $\begin{array}{l}\text { Seed weight } \\
\text { (g/Plant) }\end{array}$ & $\begin{array}{c}\text { Yield } \\
\left(\mathrm{kg} / \mathrm{hm}^{2}\right)\end{array}$ \\
\hline \multicolumn{2}{|l|}{ CONO } & 81.00 & 68.00 & 15.53 & 10.56 & 3168 \\
\hline \multicolumn{2}{|l|}{$\mathrm{C} 0 \mathrm{~N} 1$} & 81.60 & 71.13 & 15.47 & 11.00 & 3300 \\
\hline \multicolumn{2}{|l|}{$\mathrm{C} 0 \mathrm{~N} 2$} & 74.60 & 66.18 & 15.68 & 10.38 & 3113 \\
\hline \multicolumn{2}{|l|}{$\mathrm{CON} 3$} & 74.30 & 57.26 & 15.88 & 9.09 & 2728 \\
\hline \multicolumn{2}{|l|}{ C1N0 } & 76.80 & 67.86 & 15.41 & 10.45 & 3136 \\
\hline \multicolumn{2}{|l|}{ C1N1 } & 74.90 & 67.87 & 15.98 & 10.85 & 3254 \\
\hline \multicolumn{2}{|l|}{$\mathrm{C} 1 \mathrm{~N} 2$} & 75.40 & 77.85 & 15.28 & 11.90 & 3569 \\
\hline \multicolumn{2}{|l|}{ C1N3 } & 62.30 & 52.26 & 15.68 & 8.19 & 2458 \\
\hline \multicolumn{2}{|l|}{ C2NO } & 70.20 & 69.43 & 15.66 & 10.87 & 3261 \\
\hline \multicolumn{2}{|l|}{$\mathrm{C} 2 \mathrm{~N} 1$} & 72.80 & 68.09 & 16.04 & 10.92 & 3276 \\
\hline \multicolumn{2}{|l|}{$\mathrm{C} 2 \mathrm{~N} 2$} & 73.30 & 73.35 & 15.92 & 11.70 & 3510 \\
\hline \multicolumn{2}{|l|}{$\mathrm{C} 2 \mathrm{~N} 3$} & 72.30 & 72.81 & 15.46 & 11.25 & 3376 \\
\hline \multicolumn{2}{|l|}{ C3N0 } & 69.00 & 42.87 & 15.59 & 6.68 & 2005 \\
\hline \multicolumn{2}{|l|}{$\mathrm{C} 3 \mathrm{~N} 1$} & 72.50 & 68.75 & 15.43 & 10.61 & 3183 \\
\hline \multicolumn{2}{|l|}{$\mathrm{C} 3 \mathrm{~N} 2$} & 71.00 & 64.61 & 15.38 & 10.01 & 3004 \\
\hline \multicolumn{2}{|l|}{$\mathrm{C} 3 \mathrm{~N} 3$} & 68.50 & 59.14 & 15.02 & 8.88 & 2664 \\
\hline \multirow{3}{*}{ F-value } & BAR & $9.76^{* *}$ & $10.01^{* *}$ & $13.12^{* *}$ & $9.95^{* *}$ & $9.95^{* *}$ \\
\hline & NAR & $7.41^{* * *}$ & $19.95^{* *}$ & $4.86^{* *}$ & $12.08^{* * *}$ & $12.08^{* *}$ \\
\hline & $\mathrm{BAR} \times \mathrm{NAR}$ & $3.38^{* * *}$ & $12.02^{* *}$ & $9.61^{* *}$ & $5.09^{* *}$ & $5.09^{* * *}$ \\
\hline
\end{tabular}

*indicates that the difference was significant; **indicates that the difference was extremely significant. BAR indicates biochar apply rate, NAR indicates nitrogen apply rate.

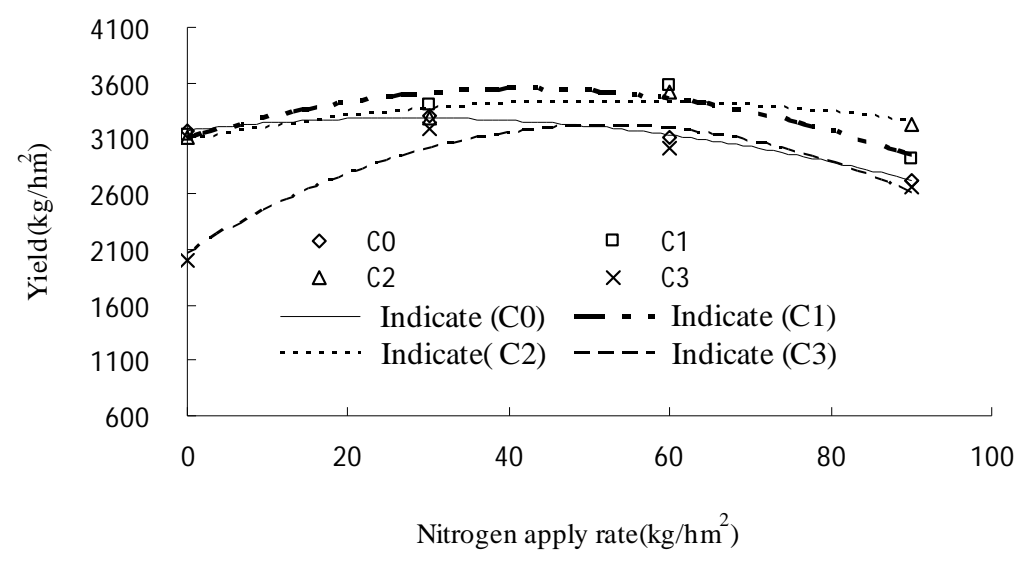

Fig. 4. Soybean yield in different rate of nitrogen application rates. 
Table 3. Relationship between optimum rate of nitrogen application and theoretical yield in different rate of biochar application.

\begin{tabular}{llccc}
\hline BAR $\left(\mathrm{kg} / \mathrm{hm}^{2}\right)$ & $\begin{array}{l}\text { Regression equation between } \\
\text { NAR and yield }\end{array}$ & $\mathrm{R}^{2}$ & $\begin{array}{l}\text { Optimum nitrogen } \\
\text { application rate } \\
\left(\mathrm{kg} / \mathrm{hm}^{2}\right)\end{array}$ & $\begin{array}{l}\text { Theoretical yield } \\
\left(\mathrm{kg} / \mathrm{hm}^{2}\right)\end{array}$ \\
\hline 0 & $\mathrm{y}=-2.16 \mathrm{x}^{2}+7.91 \mathrm{x}+211.60$ & 0.996 & 27 & 3282.9 \\
750 & $\mathrm{y}=-3.87 \mathrm{x}^{2}+21.47 \mathrm{x}+206.66$ & 0.897 & 42 & 3546.9 \\
1500 & $\mathrm{y}=-1.87 \mathrm{x}^{2}+13.16 \mathrm{x}+205.44$ & 0.800 & 52.5 & 3428.55 \\
2250 & $\mathrm{y}=-6.32 \mathrm{x}^{2}+43.93 \mathrm{x}+137.67$ & 0.912 & 52.5 & 3209.55 \\
\hline
\end{tabular}

BAR indicates biochar application rate.

The application of biochar had little effect on leaf area in the early stage of growth, but the regulation of leaf area played a certain role in the later stage of growth. The LAI of C1 was the highest among all the treatments, but with the increase of the amount of biochar applied, LAI decreased. When the amount of biochar application reached at C3, LAI was lower than that of non-biochar treatment. The chlorophyll content of biochar treatment was lower than that of no biochar treatment in the early stage of growth. But the content of chlorophyll was gradually higher than that of non-biochar treatment at the later stage of growth. It might be due to the application of biochar in the early stage of growth which inhibited the release of nitrogen fertilizer, reduced the nitrogen supply capacity of soil, and decreased the chlorophyll content. In the later stage of growth, nitrogen adsorbed by biochar gradually released, nitrogen supply capacity of soil increased, nitrogen nutrient uptake and chlorophyll content of soybean increased.

The plant height of soybean decreased with the application of biochar, and the more the amount of biochar was applied, the more the plant height decreased. Under the same biochar application level, the soybean yield increased with the increase of nitrogen application rate. When the optimum nitrogen application rate reached, the yield decreased with the continuous application of nitrogen fertilizer. $750 \mathrm{~kg} / \mathrm{hm}^{2}$ of biochar and $42 \mathrm{~kg} / \mathrm{hm}^{2}$ of nitrogen attained the best combinations for high yield of soybean in which the theoretical yield was found $3546.9 \mathrm{~kg} / \mathrm{hm}^{2}$. Combined application of biochar and nitrogen fertilizer mainly affects yield by regulating the number of seeds per plant.

Straw, as the raw material of biochar, if biochar is used as substrate to make fertilizer, it will not only help to solve the excessive utilization of nitrogen fertilizer and the related environmental problems, but also provide a new way for the effective utilization of huge straw resources. In addition, it will have important strategic significance to deal with climate change, carbon sequestration, energy crisis mitigation, food security and sustainable development.

\section{Acknowledgements}

Natural Science Fund of Heilongjiang Province, The shade-tolerance group establishment and photosynthetic mechanism study in Wild soybean (Glycine soja) (C2018059). National Natural Science Fund of China, Research on breeding potential applications of key genes related to isoflavone synthesis in Wild soybean (Glycine soja) (31771823). Major project of Research and Development of Applied Technology in Heilongjiang Province, Research on the Innovation of Germplasm Resources of Major Crops and the Technology of seed Production (GA18B101). National Key Research and Development Programme, Breeding forage and grain legumes to increase EU's and China's protein self-sufficiency (2017YFE0111000). 


\section{References}

Agegnehu G, Nelson PN and Bird M I 2016. Crop yield, plant nutrient uptake and soil physicochemical properties under organic soil amendments and nitrogen fertilization on Nitisols. Soil and Tillage Res. 160: $1-13$.

Altland JE and Locke JC 2013. Effect of biochar type on macronutrient retention and release from soilless substrate. HortSci. 48:1397-1402.

Bruun EW, Petersen CT, Hansen E and Holm JK 2014. Biochar amendment to coarse sandy subsoil improves root growth and increases water retention. Soil Use and Management. 30(1): 109-118.

Chen CR, Phillips IR and Condron LM 2013. Impacts of green waste biochar on ammonia volatilisation from bauxite processing residue sand. Plant and Soil. 367(1/2): 301-312.

Clough TJ, Condron LM, Kammann C and Muller C 2013. A review of biochar and soil nitrogen dynamics. Agronomy. 3(2): 275-293.

Gul S and Whalen JK. 2016. Biochemical cycling of nitrogen and phosphorus in biochar-amended soils. Soil Biology and Biochemistry. 103: 1-15.

Headlee W, Brewer C and Hall R 2014. Biochar as a substitute for vermiculite in pottingmix for hybrid poplar. Bioenergy Res. 7:120-131.

Lehmann J 2007. A handful of carbon. Nature. 447(7141):143-144.

Lehmann J, Rillig MC, Thies J, Masiello CA, Hockaday WC and Crowley D 2011. Biochar effects on soil biota - a review. Soil Biol. Biochem. 43(9): 1812-1836.

Li B, Fan CH, Zhang H, Chen ZZ and Sun LY 2015. Combined effects of nitrogen fertilization and biochar on the net global warming potential,greenhouse gas intensity and net ecosystem economic budget in intensive vegetable agriculture in southeastern China. Atmospheric Env. 100: 10-19.

Liao N, Li Q, Zhang W, Zhou G and Ma L 2016. Effects of biochar on soil microbial community composition and activity in drip-irrigated desert soil. European J. Soil Biol. 72: 27-34.

Liu Zhihua, Li Xiaomei, Jiang Zhenfeng, Zhang S and Wang J 2014. Effect of biochar plus fertilizer on the rhizospheric functional bacteria related to the nitrogen transformation in soybean. J. of Northeast Agricultural University. 45(8): 11-19.

Lucheta AR, Cannavan FS, Roesch LFW, Tsai SM and Kuramae EE 2016. Fungal community assembly in the Amazonian Dark Earth. Microbial Ecology 71(4): 962-973.

Mehmood K, Li JY, Jiang J 2017. Effect of low energy consuming biochars in combination with nitrate fertilizer on soil acidity amelioration and maize growth. J. Soils and Sediments. 17: 790-799.

Mete FZ, Mia S, Dijkstra FA, Abuyusuf M and Hossain ASMI 2015. Synergistic effects of biochar and NPK fertilizer on soybean yield in an alkaline soil. Pedosphere. 25: 713-719.

Novak JM, Busscher WJ 2012. Biochars impact on soil moisture-storage in an Ultisol and two Aridisols. Soil Sci. 177(3): 310-320.

Olmo M, Alburquerque J, Barron V, Campiool MCD and Gallardo A 2014. Wheat growth and yield responses to biochar addition under Mediterranean climate conditions. Biology and Fertility of Soils. 50: 1177-1187.

Partey ST, Preziosi RF and Robson GD. 2014. Short-term interactive effects of biochar, green manure, and inorganic fertilizer on soil properties and agronomic characteristics of maize. Agri Res. 3: 128-136.

Randolph P, Bansode RR, Hassan OA, Rehrah D, Ravella R, Reddy MR, Watts DW, Novak JM and Ahmedna M 2017. Effect of biochars produced from solid organic municipal waste on soil quality parameters. J. of Env Management. 192: 271-280.

Rehrah D, Bansode R R, Hassan O and Ahmesna M 2016. Physico-chemical characterization of biochars from solid municipal waste for use in soil amendment. J. of Analytical and Applied Pyrolysis. 118: 42-53.

Schnell RW, Vietor DM, Provin TL, Munster CL and Capareda S 2012. Capacity of biochar application to maintain energy crop productivity: soil chemistry, sorghum growth, and run off water quality effects. J. Environ. Qual. 41(4): 1044-1051. 
Woods WI, Falcao NPS, Teixeira WG 2006. Biochar trials aim to enrich soil for small holders. Nature. 44(7108): 144-144.

Xu Nan, Tan Guangcai, Wang Hongyuan and Gai X 2016. Effect of biochar additions to soil on nitrogen leaching, microbial biomass and bacterial community structure. European J. Soil Biol. 74: 1-8.

Zhang WM, Guan XC, Huang YW, Sun DQ and Meng J 2015. Biological effects of biochar and fertilizer interaction in soybean plant. ACTA AGRONOMICA SINICA 41(1): 109-122.

Zheng H, Wang ZY, Deng X, Herbert S and Xing B 2013. Impacts of adding biochar on nitrogen retention and bioavailability in agricultural soil. Geoderma. 206: 32-39.

Zhou ZH, L Xin-Qing, Xing Y, Fang B and Zhang LK 2011. Effect of biochar amendment on nitrogen leaching in soil. Earth and Env(china). 19(2): 278-284.

(Manuscript received on 14 June, 2018; revised on 30 March, 2019) 